\title{
Article
}

\section{Interprofessional education and practice guide: designing ethics-orientated interprofessional education for health and social care students}

Machin, L.L., Bellis, Keiran, Dixon, C., Morgan, H., Pye, J., Spencer, P. and Williams, R.A.

Available at http://clok.uclan.ac.uk/24723/

Machin, L.L., Bellis, Keiran, Dixon, C., Morgan, H., Pye, J., Spencer, P. and Williams, R.A. (2018) Interprofessional education and practice guide:

designing ethics-orientated interprofessional education for health and social care students. Journal of Interprofessional Care, 33 (6). pp. 608-618. ISSN $1356-1820$

It is advisable to refer to the publisher's version if you intend to cite from the work. http://dx.doi.org/10.1080/13561820.2018.1538113

For more information about UCLan's research in this area go to http://www.uclan.ac.uk/researchgroups/ and search for <name of research Group>.

For information about Research generally at UCLan please go to http://www.uclan.ac.uk/research/

All outputs in CLoK are protected by Intellectual Property Rights law, including Copyright law. Copyright, IPR and Moral Rights for the works on this site are retained by the individual authors and/or other copyright owners. Terms and conditions for use of this material are defined in the policies page. 


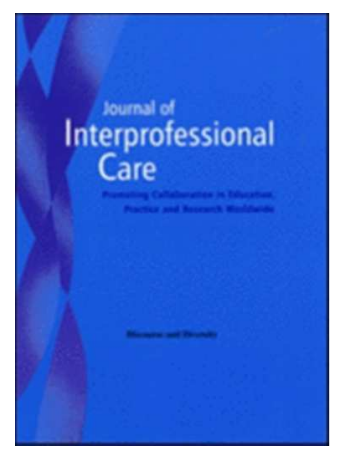

Interprofessional Education and Practice Guide: Designing ethics-orientated interprofessional education for health and social care students

\begin{tabular}{|r|l|}
\hline Journal: & Journal of Interprofessional Care \\
\hline Manuscript ID & CJIC-2017-0558.R2 \\
\hline Manuscript Type: & Interprofessional Education and Practice Guides \\
\hline Keywords: & $\begin{array}{l}\text { Clinical psychology, Ethics, Interprofessional education, Medicine, } \\
\text { Paramedicine, Social Work }\end{array}$ \\
\hline \multicolumn{2}{|c}{} \\
\hline
\end{tabular}




\title{
Interprofessional Education and Practice Guide: Designing ethics-orientated interprofessional education for health and social care students
}

\begin{abstract}
$\underline{\text { Abstract }}$
Health and social care professionals are required to work together to deliver person-centred care. Professionals therefore find themselves making decisions within multidisciplinary teams. For educators, there has been a call to bring students from differing professions together to learn to enable more effective teamwork, interprofessional communication, and collaborative practice. This multidisciplinary working is complicated by the increasingly complex nature of ethical dilemmas that health and social care professionals face. It is therefore widely recognised that the teaching and learning of ethics within health and social care courses is valuable. In this paper, we briefly make the casein support of teaching and learning health and social care ethics through the medium of interprofessional education (IPE). The purpose of this paper is provide guidance to educators intending to design ethicsorientated IPE for health and social care students. The guidance is based on the ongoing experiences of designing and implementing ethics-orientated IPE across five departments within two universities located in the North of England over a five year period. Descriptions of the ethics-orientated IPE activities are included in the guide, along with key resources recommended.
\end{abstract}

$\underline{\text { Introduction }}$ 
Health and social care has radically altered since the introduction of the National Health Service in the United Kingdom (UK) in 1948 and the associated services that now exist to address individuals' social needs alongside their health needs. Practitioners now serve individuals, families, and communities ${ }^{1}$ with complex needs, rights and entitlements that are far beyond the capacity of any one profession to respond adequately (Barr, 2014). Delivering care therefore now stems from decision-making within multidisciplinary teams. However, high-profile reports of inquiries into cases of professional error, neglect and abuse have exposed lapses in communication and collaboration between the multidisciplinary teams (Barr, 2014). The inquiries bring into stark relief the consequences of professional groups socialised into behaviour patterns and working relationships that maintain a pervasive order based on a medical hegemony (Humphris \& Hean, 2004). Hence, for educators, there has been a call to bring students from differing professions together to learn (Humphris \& Hean, 2004) to enable more effective teamwork, interprofessional communication, and collaborative practice in a manner that has been referred to as "learning together to work together" (World Health Organisation, 1988) to ensure the safe and effective treatment of patients (Williams, Onsman \& Brown, 2010).

\section{Interprofessional Education}

The fundamental premise of interprofessional education (IPE) asserts that if students from two or more professions learn from, with and about each other throughout their training they will be better prepared to deliver an integrated model of collaborative care after entering practice (Buring et al., 2009; Freeth, Hammick, Reeves, Koppel, \& Barr, 2005). 
Evaluations of IPE have highlighted that students develop greater confidence in relation to interprofessional skills (Wilhelmsson et al., 2009) and develop knowledge and skills for collaborative working, (Bolin \& Chapman, 2013; Champion, Hayward \& Hart, 2006; Hammick, Freeth, Koppel, Reeves, \& Barr, 2007; Priest et al, 2011) which have been shown to positively influence practice, resulting in improved person-centred care (Carpenter, 1995; Koppel, Barr, Reeves, Freeth, \& Hammick, 2001). In terms of designing IPE sessions, educators have identified that IPE works best with students who encounter shared ethical dilemmas (Aveyard, Edwards \& West, 2005), and have highlighted the need for students to develop shared moral language, discourse, or reflection during IPE (De Wachter, 1976; Hermsen \& Ten Have, 2005; Irvine, Kerridge \& McPhee, 2004; Purtilo, 1988).

However, much of the literature on IPE ethics training is grounded in the training and work of physicians (Caldicott \& Braun, 2011), and as a result there has been little reflection on how to design IPE to facilitate learning health and social care ethics ${ }^{2}$. Previous studies have predominately reported on the success of IPE for students from within a sole setting such as healthcare (see Hanson, 2005 for a discussion of teaching health care ethics to nursing and medical students; and Strawbridge, Barrett, \& Barlow, 2014 for a discussion on delivering IPE debates to physiotherapy and pharmacy students to learn ethics). Therefore, there is limited focus to date on the value of IPE ethics sessions that involve students that span multiple settings such as community and hospital settings (see Cino, Austin, Casa, Nebocat, \& Spencer, 2018 for a short report on providing IPE ethics education to students from dental hygiene, nursing, and medical laboratory courses). Consequently, an in-depth exploration of the considerations when designing IPE to facilitate the learning of health and social care 
ethics is needed in order to support educators in this process, and address the challenges that they face with teaching ethics more broadly.

\section{The challenges with teaching and learning health and social care ethics}

It is now widely recognised that the teaching and learning of ethics within health and social care is valuable to prepare students for the increasingly complex ethical and moral challenges facing them in future practice (Chung, Rhee, Baik, \& Oh-Sun, 2009). However, whilst high profile committees have highlighted the important role and function of ethics being part of health and social care curriculums (Boyd, 1987; General Medical Council, 2009), schools are reported to have experienced difficulty in justifying the allocation of substantial time within busy curriculums to the teaching and learning of ethics (Miyasaka, Sakai, \& Yamanouchi, 2011).

The perception of having to 'squeeze' ethics into curriculums may be a result of how the topic is understood by some students and staff, i.e., "a scaled down version of teaching moral philosophy to philosophy students" (Cowley, 2005) making it appear too abstract or removed from practice (Hugman, 2005). Studies of students' perceptions of ethics have shown that they struggle to see the value or relevance of the topic (Chung et al., 2009).

More recently, bulging curriculums have been blamed for producing strategic learners, whereby students prioritise aspects of their workload. Consequently, topics such as ethics, have been associated with softer interpersonal skills, and therefore are deemed low priority by students compared to the 'core' science and practical elements of curriculums (Willis, Williams, Brightwell, O’Meara \& Pointon, 2010). Moreover, the methods employed to teach 
ethics are also influenced by the packed curriculum, and the large student cohort sizes that can sometimes exist for health and social care courses, exacerbated by a lack of clarity about the most effective way to facilitate learning about ethics (Sanders \& Hoffman, 2010).

As educators, the need is how to make ethics appealing to students, staff, and senior management (Mattick \& Bligh, 2006) so that appropriate time and resources can be dedicated to the learning of the topic. One suggestion is to review how we deliver ethics teaching so that students learn to recognise the humanistic and ethical aspects of their careers thereby enabling them to examine and affirm their own personal and professional moral commitments (Byran, 2006; Campbell, Chin, \& Voo, 2007). In turn, students gain a greater understanding and respect for other positions and approaches, so that their ability to understand the issues and values informing different viewpoints is enhanced (Groessl, 2013; Northwest Association for Biomedical Research, 2012).

\section{The benefit of teaching and learning ethics through IPE}

Teaching and learning ethics through IPE are natural bedfellows resulting from the overlap in purpose and outcomes. Firstly, the aims and objectives of IPE and ethics coincide with each other. Both IPE and ethics intend to ultimately improve the care and service that the public receive from health and social care practitioners. Ethics is commonly understood as the study of what is good and bad, right and wrong, and of moral duty and obligation (Clark, Cott \& Drinka, 2007). It also includes the values and principles of conduct governing an individual or a group. The nature of ethics means that very often there is no clear or correct path to follow when considering ethical dilemmas in practice. Therefore, the opportunity for 
students to come together to consider ethics offers the mutual benefit of learning about ethical, personal and professional values, as well as the factors that influence other professionals in their decision-making.

Secondly, there is widespread support from international education experts, the UK government and prominent organisations representing health and social care practitioners for the inclusion of both IPE as a method of teaching and of ethics in health and social care training, e.g., the Interprofessional Educational Collaborative (2016), the Department of Health (2000), the Health Care Professions Council (2017), the British Psychological Society (2015) and the College of Paramedics (2017).

Thirdly, the notion that teaching and learning ethics is the business of one particular academic discipline or the concern of any single professional has long been criticised (Campbell et al., 2007). Discussions of 'ethical stress' (Fenton, 2016) and 'ethical erosion' (Swenson \& Rothstein, 1996) whereby students may feel pressured to relinquish their ethical values whilst on placements as they observe 'unethical' behaviours from qualified practitioners (Roff \& Preece, 2004) have illustrated that health and social care ethics has to be multidisciplinary in nature and delivered by multiple professionals. Teaching and learning ethics through IPE demonstrates that ethics matters to all health and social care practitioners.

Given the strength of arguments for the teaching and learning ethics to health and social care students through the means of IPE, it is timely to explore how ethics-orientated IPE can be designed when deciding to include it within a curriculum. 


\section{Key lessons of designing ethics-orientated IPE for health and social care students}

What follows are key lessons to consider when designing ethics-orientated IPE for health and social care students. The lessons are based on the ongoing experiences of designing and implementing ethics-orientated IPE across five departments, within two universities located in the North of England over a five year period. Whilst much literature exists around the designing of IPE generally, or for students from a specific setting, our own experience highlights that there is limited literature available that focuses solely on designing ethicsorientated IPE for health and social care students. Therefore to avoid duplication and be able to make a novel contribution to knowledge surrounding IPE, the focus of the key lessons presented here are on combining IPE and ethics. We envisage the lessons to be read in conjunction with existing pedagogical literature when designing innovative teaching such as debates, seminars, and forums in higher education.

\section{- Look to practice when deciding the format of IPE}

When designing ethics-orientated IPE, it is valuable to look to practice when deciding the format and structure. Ideally, the format of IPE will reflect real-world practice, hence some institutions have dedicated physical space for IPE, such as moot courts and simulation suites. However, not every institution has such resources available when designing IPE, but still wish to retain the real-world feel to IPE. For example, wanting to demonstrate clinical ethics in practice, innovative medical educationalists have initiated pseudo-clinical ethics committees, which they believe could be adapted for medical students. For those that took part in the pseudo committees, they were seen as playing a useful role in offering advice, 
support and information, and were a useful experience for those wishing to learn about clinical ethical decision-making and hospital ethics committees (Johnston et al., 2012; Rostain \& Parrott, 1986). We opted to extend the pseudo-clinical ethics committee to Social Work, Medicine, and Clinical Psychology students to reflect the membership of UK clinical ethics committees (Insert Table 1 about here). We also included the common ethical frameworks, such as Four Principles (Beauchamp \& Childress, 1989), Four Quadrants (Jonsen, Siegler \& Winslade, 1982), and Seedhouse Grid (Seedhouse, 2009), used by the real-world clinical ethics committees when students analysed and discussed the cases. By reflecting practice, students gained awareness of the real-world clinical ethics committees and obtained insight into the workings and purpose of the committees, which they are likely to encounter during practice, as well as consider becoming a member of a committee in the future (Johnston et al, 2012).

- Look to practice when deciding the theme of IPE

Looking to practice when deciding the theme of ethics-orientated IPE can highlight the relevance and applicability to students of learning ethics (Johnston et al., 2012). For example, an ageing population, the replacement of the Liverpool Care Pathway, and debates surrounding what makes a 'good death' reinforces the value of ethics-orientated IPE on the theme end of life care. We decided to include ethics-orientated IPE debates with multidisciplinary teams made up of Social Work and Medicine students debating motions on end of life care (see Table 1). Students therefore appreciate the range of ethical arguments surrounding end of life care by both participating in the debates, as well as watching other students debate related motions. Alternatively, rather than focusing on a specific topic, it is 
possible to design ethics-oriented IPE on specific ethical concepts, such as rationing, resource allocation and justice, that hold relevance to an extensive range of student groups, like Medicine and Health Care Management. Others have argued in favour for IPE for these two professional groups to come together at the earliest possible stage in professional education in order to facilitate a deeper understanding of each other's culture and language and therefore improve relationships between them and the quality of care provided to patients and relatives (Nash, 2003; Strawbridge et al., 2014). By focusing on a broad ethical concept such as rationing, the IPE serves the dual purpose of ethical learning, as well as initiating much-needed dialogue between Medical and Management students on striking a balance between the dimensions of patient ethics, equity, efficiency, and choice (Atun, 2003).

- Take time to evaluate

The importance of considering evaluation as early as possible in the design process has been stressed in the literature, as has maintaining clarity over the purpose of evaluation (Reeves, Boet, Zierler \& Kitto, 2015). Feedback is not intended to give reassurance to educators that they are delivering a positive experience to students, nor is it intended to provide evidence of quality assurance to the department or educational organisation. In the light of past experience, we have modified our feedback sheet (insert Table 2 about here) to give greater recognition to the fact that the process of reflection about feedback can be an important part of consolidating learning. For our ethics-orientated IPE, we now use feedback questions tailored to the specific session rather than generic feedback questions. We focus on the 
content of the teaching, keep the number of questions to a minimum, and avoided closed questions. Crucially, we have designed the feedback sheets so that they encourage the student to reflect on the IPE objectives and messages such as teamwork skills, communications skills, and ethical and legal reasoning. We also explain the purpose of completing the feedback sheet to the students prior to completing it so they view the reflection required as part of their continued learning.

\section{- Draw on students' training in the field}

Aims of teaching health and social care ethics can include, reasoning skills, identifying a legitimate resolution to a problem, as well as be able to explain and justify the resolution (Johnston \& Haughton, 2007). In our Clinical Ethics Committees, students from different professional backgrounds are expected to come together to explore an ethical dilemma that they have faced in a practice setting. Each student shares a dilemma with their group and decides which case to analyse using an ethical framework. The main aim is to improve the quality of students' care for those they serve by focusing on the skills associated with practical ethical reasoning and decision-making. The students present cases and learn how to identify and anticipate ethical issues, distinguish them from legal and social issues, determine the relevant principles and concepts, where they clash and why, and state their ethical decision, specifying how the guiding principles should be balanced and justifying their arguments and decisions (Mitchell, Myser, \& Kerridge, 1993). Evidence suggests that when students use these real-life problems as a point of discussion, learning is effective especially when a joint problem solving approach is taken in a multidisciplinary forum (Gawthrop and Uhlemann, 1992; Groessl, 2013). 


\section{- $\quad$ Consider the timing of ethics-orientated IPE}

There is much debate surrounding when IPE should take place within a curriculum. Some authors defer to the level of experience during placements and exposure to ethical challenges in practice (Mandy, Milton, \& Mandy, 2004) with evidence suggesting that students do not appear to gain favourably from IPE early on in their course (Yearsley, 2007). Others consider the need for students to have a sense of professional identity. Most students are able to differentiate their own profession from other groups early in their education, at least in relation to some attributes, which suggests there is no reason to delay interprofessional interaction until later in training. However, Herbert, Meslin, and Dunn (1992) claim students' ethical sensitivity, i.e., an ability to identify ethical issues, decreases in the later part of training with a lack of time for reflection and a focus on scientific medical knowledge being blamed (Johnston et al., 2012). This suggests a balance has to be struck in terms of when IPE takes place with educators considering the openness of students to learning, their experiences from clinical, community and practice settings, and their ability to form a professional identity. In addition to this, there is the need to ensure equity in experience and identities between the student groups brought together during IPE, so the learning is mutually beneficial. This is particularly pertinent when combining students on undergraduate and postgraduate courses. We therefore conduct IPE with Medical students in their fourth and fifth years of training, when they have more clinical exposure and ethical training, and with Masters Social Work and Doctoral Clinical Psychology students. 
- $\quad$ Take time to reflect on students' wider learning so far

There is a need to co-ordinate the timing of when ethics-orientated IPE takes place within a curriculum (see above) along with students' previous learning and developing skill sets. We designed our ethics-orientated IPE so that more challenging activities, such as the Clinical Ethics Committees, took place in later years of students' training. The Clinical Ethics Committees demand higher reasoning and communication skills compared to other ethicsorientated IPE activities as students work within groups involving three different professions, use complex ethical frameworks, analyse each other's experiences, and provide advice to colleagues facing ethical uncertainty. Furthermore, we also reflected on how ethics-orientated IPE could provide progression within our wider curriculums by designing activities, such as the Capacious Suicide Seminars and End of Life Debates, that enable students to apply and critique core ethical concepts - best interests, autonomy, and capacity - learned in earlier years of their training. Similarly, the Clinical Ethics Committees involve Medical students using advanced ethical frameworks to provide structure to the Forum discussions, which develop their knowledge of ethical frameworks gained in previous years, and the IPE component of the End of Life Debates, enable students to build on their earlier experiences of debates. In essence, when designing ethics-orientated IPE, take time to reflect on how the activity can provide opportunity to build on students' learning from earlier in the curriculum, and enable progression in students' skills and knowledge.

- Prepare students ahead of IPE taking place 
Students need to be prepared for IPE through educators providing opportunity for reflection on their own professional identity and on the stereotypical views that they may hold both about their own profession and those they will be engaging with (Bell \& Allain, 2011). This is particularly important in the context of teaching health and social care ethics because of the value-laden nature of what is discussed in the sessions, and individuals may hold strongly felt views about the topics under consideration. From our experience, it is also common to see student groups feeling apprehensive or vulnerable about sharing their knowledge or ignorance with other vocational students. Some preparation and prior information can be helpful in serving to provide reassurance and break down these concerns. We believe this to be particularly important to our ethics-orientated IPE because there is often a considerable disparity of age and life-experience between some of the groups, e.g., the Pre-Hospital Care Forums (see Table 1).

In some sessions, we email preparatory reading to inform participants well in advance about the other professional groups who will be attending, along with information about where those other groups are in their training, their level of experience and anticipated level of knowledge. This helps to give reassurance to participants that they are neither over- nor under-qualified to bring thoughts and ideas to the session. It also gives participants more confidence in initiating discussions with their partner professionals because they have at least some insight into their background and likely level of knowledge and experience.

We build in time in the small group sessions for initial face-to-face introductions and discussions about each participant's background and level of training. This works well for activities such as our Pre-Hospital Care Forums and Clinical Ethics Committees, which are attended by a mix of undergraduate students, postgraduate students and students with 
considerable previous experience as frontline ambulance technicians. Student preparation also extends to considering how to introduce students to the aims and objectives of the IPE activity, and clarification of any 'ground rules' for the session. From our experience, this is best delivered as an initial whole group introduction in which we highlight the benefits of delivering the present teaching through the medium of IPE. We stress the importance of upholding principles of confidentiality, as well as the personal and emotive nature of much of what is being discussed and therefore the importance of valuing and respecting one another's views.

\section{- Create a safe space for students to learn}

Grasping what is meant by ethics and ethical decision-making is not a straightforward linear process - it is complex. Issues around ethics are bound up with personal values meaning that understanding ethics can be personally challenging as questions about our own beliefs and attitudes are unpicked or challenged. There are, of course, different ways of thinking about ethics, one of which is the idea that ethics do not 'exist' as an objective fact, but are instead grown from whatever situation students are working with at the time (Hugman, 2005) combined with students' own value bases. This recognition of the subjective nature of ethics and values requires a safe space for students to explore their own values (Bryan, 2006) and their own construction of understanding about ethical practice. Students must therefore be supported to be reflexive during ethics-orientated IPE. We therefore require IPE facilitators to encourage students to recognise that there are potentially several 'right' answers to any ethical dilemma discussed (Gray \& Gibbons, 2007) and that managing uncertainty is a significant ingredient of professional practice (Taylor \& White, 2006). 
- Involve practitioners and the people we serve in supporting students' learning

Beresford (2000), writing in the context of Social Work, reminds us how much professionals can learn from the people they serve. Teaching ethics-orientated IPE provides an ideal opportunity to bring together service users, patients, clients and practitioners to support the learning of students given the focus on 'real life'. Students learn what is important to the people they serve, positions the people they serve at the heart of health and social care, thereby enhancing person-centred care (Mahoney, Mulder, Hardesty, \& Madan, 2017). In our End of Life Debates, we involve a range of practitioners from local hospices, hospitals and community, who form a judging panel. The Social Work and Clinical practitioners ask questions to the debate teams, decide the winning team of each debate, provide feedback to the students, and form a panel question and answer session at the end of the debates. We plan to extend this involvement to include lay members to support students when developing their debate motions.

\section{- $\quad$ Build in flexibility for group preferences}

For Cowley (2005), learning an 'ethics' vocabulary in an attempt to gather ethical expertise can hinder and obstruct students from thinking and discussing dilemmas and argues our own vocabularies are sufficient to make sense of and deal with ethical challenges in practice. During IPE, groups should therefore be encouraged to define their own terms, and explore each other's understanding of ethical jargon. Therefore in the Clinical Ethics 
Committees, a range of ethical frameworks are provided to create choice and students are encouraged to use what works for them as a group. Students and facilitators are encouraged to accept that groups will respond differently to the resources provided to structure the session and that the session may differ across groups. Similarly, in the End of Life Debates, each interprofessional debate team are provided with the same large resource pack, which includes a range of journal articles from different disciplines (ethics, law, sociology) and professions (medical, nursing, social work) and suggested internet resources to prepare for their debate. Teams are encouraged to read the resources and share their findings and observations with the rest of their team. The variety of resources mean that the teams can explore what is of interest to them as a group, and therefore can have different discussions to other debate teams. Equally, individual students can have different preferences as to which resources are used, but the interprofessional element of the teams mean that there is the potential to learn of alternative views on the debate motion.

\section{- $\quad$ The importance of debriefing opportunities for students}

The importance and value of debriefing, and strategies for conducting debriefing are wellrecognised (Decker et al., 2013). Debriefing sessions are reflective discussions that take place following an event, whether that be a live incident or simulated encounter. The process allows students to discuss a number of issues including what they have learned, how they would cope with a similar situation in future, how the content affected them emotionally, and how it has affected their self-confidence. Ethics-orientated IPE necessarily touches on a number of very sensitive and personal topics that may have particular 
resonance for some students. Sensitive and confidential debriefing therefore merits particular consideration by educators.

Furthermore, the importance of debriefing to preserve mental wellbeing after stressful incidents is being given ever-greater emphasis thanks to campaigns such as the 'Blue Light Champion' project promoted by the charity MIND. The process of participating in debriefing sessions should therefore also be seen as an important learning exercise (MIND, 2017). The need for debrief in ethics-orientated IPE was brought to our attention during our Capacious Suicide Seminars, whereby students work through a scenario describing a person in his own home at risk of committing suicide, which prompt critical discussion of the legal, ethical and moral codes surrounding capacity assessment. Aware that some students might have experience of, or witnessed, suicide attempts, we therefore ask facilitators to incorporate debriefing into their small group sessions. This has the advantage of maintaining the feeling of confidentiality and intimacy that has built up through the small group sessions, and capitalizes on the trust and mutual support that will have developed within the groups. We also follow this with a large group debrief and summing up for all students in order to reinforce what learning points we expect them to take away, and acknowledge once again the sensitive and personal nature the topics discussed. This is also an opportunity to signpost students to additional sources of support should they feel the need.

\section{$\underline{\text { Discussion }}$}

Effective health and social care delivery in hospital and community sectors requires all health and social care professionals involved to work collaboratively within and between teams to ensure the best possible outcome for the people they serve (Department of Health, 2000; Mental Health Commission, 2016). IPE is a method that encourages students 
to explore how their professions can work together to respond more fully to the complex needs of the people they serve (Barr, Low \& Howkins, 2012). IPE enables health and social care students to understand different professional perspectives, cultures, norms, and language (Yearsley, 2007), which can help overcome ignorance and prejudice among health and social care professionals (Department of Health, 2001) and inform and inspire closer collaboration between them to improve services and the care delivered (Barr, 2014). The positive evaluation of IPE explains why it is a mandatory requirement of qualifying health and social care training in England and Wales (Health Care and Professions Council, 2017) and this high profile support can be utilised when making the case to create space within busy curriculums for ethics-orientated IPE.

We have created this guide to assist health and social care educators when setting out to combine the teaching of health and social care ethics with IPE. The guide outlines our key lessons from designing and implementing ethics-orientated IPE over the past five years. We have described the various ethics-orientated IPE that we conduct, which highlight the ethical topics, concepts and frameworks that can be used, as well as provided examples of how to debrief students, and feedback formats that continue the students' learning postIPE. For us, successful ethics-orientated IPE lies with presenting health and social care ethics as a practical framework, as opposed to a theoretical body of knowledge, to make it relevant and applicable to students. In summary, ethics-orientated IPE creates a richer learning experience and fosters higher-level reasoning skills within students.

\section{Endnotes}


1. Mindful of the range of terms that can be used to describe the people that each health and social care professional interacts with such as patients, clients, service users, a number of inclusive phrases have been agreed upon between authors, e.g., "serving individuals, families, and communities" and "person-centred services" in order to accommodate the differences between professional groups.

2. A range of descriptors can be used for ethics within each professional curriculum such as medical, clinical, healthcare. In this manuscript, the authors opted for the umbrella term "health and social care ethics" in order to accommodate the diversity in terminology.

\section{Acknowledgements}

We would like to express our gratitude to the senior management teams within our departments and institutions for their continued support towards our ethics-orientated IPE. We also would like to thank all the facilitators within our departments who make ethicsorientated IPE possible. Finally, we wish to thank our students for engaging so willingly in our ethics-orientated IPE.

\section{Key Resources}

UK Clinical Ethics Network: http://www.ukcen.net/ provides background information on clinical ethics, frameworks that can be used when discussing ethical cases, and case studies. 
Institute of Medical Ethics: http://www.instituteofmedicalethics.org/website/ provides curriculum content guidance as well as teaching and learning resources on medical ethics including video clips, films, journal articles, textbooks, websites.

The College of Paramedics:

https://www.collegeofparamedics.co.uk/?gclid=EAlalQobChMI7raTglzm1wIVTrXtCh1sXg5N EAAYASAAEgJ CPD BwE provides free e-learning packages for paramedics that include case studies reviewing legal and ethical aspects of paramedicine.

The British Psychological Society Guidance on Teaching and Assessment of Ethical Competence in Psychology Education (2015) provides information on appropriate ethical knowledge and practice at all levels of study in psychology https://www.bps.org.uk/sites/beta.bps.org.uk/files/Policy\%20\%20Files/Guidance\%20on\%20Teaching\%20and\%20Assessment\%20of\%20Ethical\%20Compe tence\%20in\%20Psychology\%20Education\%20(2015).pdf

The Higher Education Academy provides a series of searchable blogs and Knowledge Hub Resources, www.heacademy.ac.uk

Thomas, J. \& Baron, S. (2012) Curriculum Guide: Interprofessional and inter-agency collaboration. London: The College of Social Work Available at https://www.basw.co.uk/resource/?id=4829

The British Association of Social Workers promotes a Code of Ethics for all social workers to abide by available at: https://www.basw.co.uk/codeofethics/

A curriculum guide to support the development of interprofessional education is hosted by the British Association of Social Workers and available at: 
https://exchange.lancs.ac.uk/owa/redir.aspx?C=K Id8NUoW 8yFGWNTMnBdqJ7DBJAsIw50

HiLFwc9niSkui4KFDvVCA..\&URL=https\%3a\%2f\%2fwww.basw.co.uk\%2fresource\%2f\%3fid\%3

$\underline{\mathrm{d} 4829}$

$\underline{\text { Declaration of interests }}$

The authors report no conflict of interests. The authors alone are responsible for the content and writing of this article. 


\section{References}

Atun, R.A. (2003). Doctors and managers need to speak a common language. British Medical Journal, 326, 655 .

Aveyard, H., Edwards, S., \& West, S. (2005). Core topics of health care ethics. The identification of core topics for interprofessional education. Journal of Interprofessional Care, 19, 63-69.

Barr, H. (2014). Interprofessional Education. In Cockerham W.C., Dingwall, R. and Quah, S.R. (Eds.), The Wiley Blackwell Encyclopedia of Health, IIIness, Behaviour and Society. New Jersey: Wiley-Blackwell.

Barr, H., Low, H., \& Howkins, E. (2012). Interprofessional education in pre-registration courses: a CAIPE guide for commissioners and regulators of education. London: CAIPE.

Beauchamp, T.L., \& Childress, J.F. (1989). Principles of biomedical ethics. Oxford: Oxford University Press.

Bell, L., \& Allain, L. (2011). Exploring professional stereotypes and learning for interprofessional practice: An example from UK qualifying level social work education. Social Work Education, 30, 266-280.

Beresford, P. (2000). Service users' knowledges and social work theory: Conflict or collaboration? British Journal of Social Work, 30, 489-503.

Bolin, B.L., \& Chapman, S. (2013). Graduate social work students: Reflecting on inter 
professional education with medical students. Reflections, 19, 24-27

Boyd, K.M. (1987). Report of a working party on the teaching of medical ethics - Chairman Sir Desmond Pond (The Pond Report). London: IME Publications.

British Psychological Society. (2015). Guidance on teaching and assessment of ethical competence in psychology education. Leicester: BPS.

Byran, V. (2006) Moving from professionally specific ideals to the common morality. Journal of Teaching in Social Work, 26, 1-17.

Buring, S.M., Bhushan, A., Brazeau, G., Conway, S., Hansen, L., \& Westberg, S. (2009). Keys to successful implementation of interprofessional education: Learning location, faculty development, and curricular themes. American Journal of Pharmaceutical Education, 73, 60.

Caldicott, C.V. \& Bruan, E.A. (2011). Should professional ethics education incorporate singleprofessional or interprofessional learning? Advances in Health Science Education, 16, 143-146.

Campbell, A.V., Chin, J., \& Voo, T.C. (2007). How can we know that ethics education produces ethical doctors? Medical Teacher, 29, 431-436.

Carpenter, J. (1995). Doctors and nurses: stereotypes and stereotype change in interprofessional education. Journal of Interprofessional Care, 9, 151-161.

Champion, M., Hayward, M, \& Hart, K. (2006). Interprofessional education: Even clinical psychologists can do it. Clinical Psychology Forum, 167, 38-41. 
Chung, E-K., Rhee, J-AE., Baik, Y-H., \& Oh-Sun, A. (2009). The effect of team-based learning in medical ethics education. Medical Teacher, 31, 1013-1017.

Cino, K., Austin, R., Casa, C., Nebocat, C., \& Spencer, A. (2018). Interprofessional ethics education seminar for undergraduate health science students: A pilot study. Journal of Interprofessional Care, 32, 239-241.

Clark, P. G., Cott, C., \& Drinka, T. J. (2007). Theory and practice in interprofessional ethics: A framework for understanding ethical issues in health care teams. Journal of interprofessional care, 21, 591-603.

College of Paramedics. (2017). Paramedic curriculum guidance $\left(4^{\text {th }}\right.$ Edition) retrieved from https://www.collegeofparamedics.co.uk/downloads/FINAL Paramedic Curriculum Guidance Handbook Sept 2017.pdf

Cowley, C. (2005). The dangers of teaching medical ethics. Journal of Medical Education, 31, 739-742.

De Wachter, M. (1976). Interdisciplinary teamwork. Journal of Medical Ethics, 2, 52 - 57.

Decker, S., Fey, M., Sideras, S., Caballero, S., Rockstraw, L., Boese, T., Franklin, A.E., Glow, D., Lioce, L., Sando, C.R., Meakim, C., \& Borum. J.C. (2013). Standards of best practice: Simulation standard VI: The debriefing process. Clinical Simulation in Nursing, 9(6S), S27-S29.

Department of Health. (2000). The NHS plan. A plan for investment. London: Department of Health. 
Department of Health (2001). Working together, learning together - a framework for lifelong learning for the NHS. London-Department of Health

Fenton, J. (2016). Values in social work: Reconnecting with social justice. London: Palgrave.

Freeth, D., Hammick, M., Reeves, S., Koppel, I., \& Barr, H. (2005). Effective interprofessional education: Development, delivery and evaluation. Oxford: Blackwell.

Gawthrop, J.C., \& Uhlemann, M.R. (1992). Effects of the problem-solving approach in ethics training. Professional Psychology: Research and Practice, 23, 38-42.

General Medical Council. (2009). Tomorrow's doctors; Recommendations on undergraduate medical education. London: GMC.

Gray, M., \& Gibbons, J. (2007). There are no answers, only choices: Teaching ethical decision making in social work. Australian Social Work, 60, 222-238.

Groessl, J. (2013). An interdisciplinary ethics module for MSW and nursing students. Social Work Education, 32, 639-649.

Hammick, M., Freeth, D., Koppel, I, Reeves, S., \& Barr, H. (2007). A best evidence systematic review of interprofessional education: BEME guide no.9. Medical Teacher, 29, 735751.

Hanson, S. (2005). Teaching health care ethics: why we should teach nursing and medical students together. Nursing Ethics, 12, 167-176.

Health Care and Professions Council. (2017). Standards of education and training. London: HCPC. 
Herbert, P., Meslin, E.M., \& Dunn, E.V. (1992). Measuring the ethical sensitivity of medical students; A study at the university of Toronto. Journal of Medical Education, 18, 142147.

Hermsen, M., \& Ten Have, H. (2005). Decision-making in palliative care: Continuing a dialogue. Patient Education \& Counselling, 58, 119-20.

Hugman, R. (2005). Exploring the paradox of teaching ethics for social work practice. Social Work Education, 24, 535-545.

Humphris, D., \& Hean, S. (2004). Educating the future workforce: Building the evidence about interprofessional learning. Journal of Health Services Research and Policy, 9, 24-7.

Interprofessional Education Collaborative. (2016). Core competencies for interprofessional collaborative practice: 2016 update. Washington, DC: Interprofessional Education Collaborative.

Irvine, R., Kerridge, I., \& McPhee, J. (2004). Towards a dialogical ethics of interprofessionalism. Journal of Postgraduate Medicine, 50, 278 - 280.

Johnston, C., \& Houghton, P. (2007). Medical students' perceptions of their ethics teaching. Journal of Medical Education, 33, 418-422.

Johnston, C., Williams, C., Dias, C., Lapraik, A., Marvdashti, L., \& Norcross, C. (2012). Setting up a student clinical ethics committee. Clinical Ethics, 7, 51-53.

Jonsen, A.R., Siegler, M., \& Winslade, W.J. (1982). Clinical ethics: A practical approach to ethical decisions in clinical medicine. York: Macmillian. 
Koppel, I. Barr, H., Reeves, S., Freeth, D., \& Hammick, M. (2001). Establishing a systematic approach to evaluating the effectiveness of interprofessional education. Issues in Interprofessional Care, 3, 41-49.

Mahoney, J.S., Mulder, C., Hardesty, S., \& Madan, A. (2017). Integrating caring into patientcentred care through interprofessional education and ethics: The caring project. Bulletin of the Menninger Clinic, 81, 233-246.

Mandy, A., Milton, C., \& Mandy, P. ( 2004). Professional stereotyping and interprofessional education. Learning in Health and Social Care, 3, 154-170.

Mattick, K. \& Bligh, J. (2006). Getting the measure of interprofessional learning. Medical Education, 40, 399-400.

Mental Health Commission. (2016). Annual Report 2016. Dublin: Mental Health Commission.

MIND. (2017). Our Blue Light. Retrieved from https://www.mind.org.uk/newscampaigns/campaigns/bluelight/our-blue-light/

Mitchell, K.R., Myser, C., \& Kerridge, I.H. (1993). Assessing the clinical ethical competence of undergraduate medical students. Journal of Medical Education, 19, 230-236.

Miyasaka, M., Sakai, S., \& Yamanouchi, H. (2011). How should ethics be taught to medical, nursing and other healthcare students? Eubios Journal of Asian and International Bioethics, 21, 91-95.

Nash, D.B. (2003). Doctors and managers: mind the gap. British Medical Journal, 326,652-3. 
Northwest Association for Biomedical Research. (2012). Bioethics 101: Reasoning and Justification. $\quad$ https://www.nwabr.org/teacher-center/bioethics-101\#overview accessed 12.12.17

Priest, H., Roberts, P., Dent, H., Hunt. T., Weston, D., Chell, A., Blincoe, C., \& Armstrong, C. (2011). Preparing for collaborative working in mental health: An interprofessional education project with clinical psychology trainees and nursing students. Journal of Mental Health Training, Education \& Practice, 6, 47-57.

Purtilo, R.B. (1988). Ethical issues in teamwork: The context of rehabilitation. Archives of Physical Medicine and Rehabilitation, 69, 318-22

Reeves, S., Boet, S., Zierler, B., \& Kitto, S. (2015). Interprofessional education and practice Guide No. 3: Evaluating interprofessional education. Journal of Interprofessional Care, 29, 305-312.

Roff, S., \& Preece, P. (2004). Helping medical students to find their moral compasses: Ethics teaching for second and third year undergraduates. Journal of Medical Education, 30, 487-489.

Rostain, A.L., \& Parrott, M.C. (1986). Ethics committee simulations for teaching medical ethics. Journal of Medical Education, 61, 178-181.

Sanders, S., \& Hoffman, K. (2010). Ethics education in social work: Comparing outcomes of graduate social work students. Journal of Social Work Education, 46, 7-22.

Seedhouse, D. (2009). Ethics: The heart of health care. London: Wiley-Blackwell. 
Strawbridge, J.D., Barrett, A.M., \& Barlow, J.W. (2014). Interprofessional ethics and professionalism debates: findings from a study involving physiotherapy and pharmacy students. Journal of Interprofessional Care, 28, 64-65.

Swenson, S.L., \& Rothstein, J.A. (1996). Navigating the wards: Teaching medical students to use their moral compasses. Academic Medicine, 71, 591-594.

Taylor, C., \& White, S. (2006). Knowledge and reasoning in social work: Educating for humane judgement. British Journal of Social Work, 36, 937-954.

Thistlethwaite, J. (2012). Interprofessional education: a review of context, learning and the research agenda. Medical education, 46, 58-70.

Wilhelmsson, M., Pelling, S., Ludvigsson, J., Hammar, J., Dahgren, L-O., \& Faresjo, T. (2009). Twenty years experience of interprofessional education in Linköping groundbreaking and sustainable. Journal of Interprofessional Care, 23,121-33.

Williams, B., Onsman, A., \& Brown, T. (2010). The changing Australian landscape: implications for Paramedics. Journal of Paramedic Practice, 2, 580-584.

Willis, E., Williams, B., Brightwell, R., O’Meara, P., \& Pointon, T. (2010). Road-ready paramedics and the supporting science curriculum. Focus on Healthcare Professionals: A Multidisciplinary Journal, 11, 1-11.

World Health Organisation. (1988). Learning together to work together for health. Geneva: WHO. 
Yearsley, S. (2007). A literature review analysing current research into undergraduate interprofessional learning in the health and social care context. Practitioner Research into Higher Education, 1, 56-58. 


\begin{tabular}{|c|c|c|c|c|}
\hline & Clinical Ethics Committees & Pre-hospital Care Forums & Capacious Suicide Seminars & End of Life Debates \\
\hline $\begin{array}{l}\text { Purpose, aims } \\
\text { or objectives } \\
\text { of activity }\end{array}$ & $\begin{array}{l}\text { To enhance professional } \\
\text { practice. } \\
\text { To hone decision-making } \\
\text { skills. } \\
\text { To facilitate inter-professional } \\
\text { learning. } \\
\text { There is an emphasis on } \\
\text { attitudes and } \\
\text { teamwork/interpersonal skills, } \\
\text { communication, and increased } \\
\text { understanding of respective } \\
\text { roles. }\end{array}$ & $\begin{array}{l}\text { Foster interpersonal and ir } \\
\text { Emphasis on attitudes and } \\
\text { communication, and unde } \\
\text { Interactive rather than pas } \\
\text { Promote collaborative car }\end{array}$ & $\begin{array}{l}\text { orofessional respect. } \\
\text { nwork/interpersonal skills, } \\
\text { ding of respective roles. } \\
\text { learning. }\end{array}$ & $\begin{array}{l}\text { To facilitate inter-professional } \\
\text { learning. } \\
\text { To develop critical thinking and } \\
\text { analytical skills. } \\
\text { To gain insight into the ethical aspects } \\
\text { surrounding end of life care. }\end{array}$ \\
\hline $\begin{array}{l}\text { When the } \\
\text { activity takes } \\
\text { place }\end{array}$ & $\begin{array}{l}\text { For Doctorate in Clinical } \\
\text { Psychology students, in } 1^{\text {st }} \text { and } \\
2^{\text {nd }} \text { year of a } 3 \text { year } \\
\text { programme. } \\
\text { For Medical Undergraduate } \\
\text { students, in } 5^{\text {th }} \text { (final) year. } \\
\text { For Undergraduate Social } \\
\text { Work students in } 3^{\text {rd }} \text { (final) } \\
\text { year, and for Masters Social } \\
\text { Work students in } 2^{\text {nd }} \text { (final) } \\
\text { year. }\end{array}$ & $\begin{array}{l}\text { For Medical Undergraduat } \\
\text { For Paramedic students, } 2\end{array}$ & $\begin{array}{l}\text { dents, } 4^{\text {th }} \text { year of a } 5 \text { year degree. } \\
\text { al) year of course. }\end{array}$ & $\begin{array}{l}\text { Social Work Masters students, } 1^{\text {st }} \text { year } \\
\text { of a } 2 \text { year degree. } \\
\text { Medical Undergraduate students, } 4^{\text {th }} \\
\text { year of a } 5 \text { year degree. }\end{array}$ \\
\hline
\end{tabular}




\begin{tabular}{|c|c|c|c|c|}
\hline $\begin{array}{l}\text { Where the } \\
\text { activity occurs }\end{array}$ & $\begin{array}{l}\text { On university campus. } \\
\text { Requires use of approximately } \\
20 \text { small rooms e.g. capacity } \\
\text { for } 10 \text { people. }\end{array}$ & \multicolumn{2}{|c|}{$\begin{array}{l}\text { On university campus. } \\
\text { Requires use of one medium-sized lecture theatre e.g. capacity } \\
\text { for } 100 \text { students, and } 10 \text { small rooms e.g. capacity for 10-15 } \\
\text { people. }\end{array}$} & $\begin{array}{l}\text { On university campus. } \\
\text { The day of students preparing their } \\
\text { debate presentations, one medium- } \\
\text { sized lecture theatre e.g. capacity for } \\
100 \text { students, and space which can be } \\
\text { used by students for small group } \\
\text { discussions e.g. foyers, break out } \\
\text { areas, meeting rooms, seminar rooms. } \\
\text { On the day of the debates, two rooms } \\
\text { are required in order to accommodate } \\
\text { half of the students in each room. The } \\
\text { room needs to have space for students } \\
\text { to present their debate presentations, } \\
\text { for the tutor to chair the debates, and } \\
\text { a judges panel. }\end{array}$ \\
\hline $\begin{array}{l}\text { How the } \\
\text { activity is } \\
\text { structured }\end{array}$ & $\begin{array}{l}\text { Two hour session. } \\
\text { Students receive a short } \\
\text { briefing from their course } \\
\text { tutor in advance of the } \\
\text { session. The briefing can be } \\
\text { done via email or lecture. All } \\
\text { students receive a pack } \\
\text { consisting of preliminary } \\
\text { reading of the ethical } \\
\text { frameworks that will be used } \\
\text { during the Clinical Ethics } \\
\text { Committees, and an outline of } \\
\text { the format of the session. All } \\
\text { students are asked to come }\end{array}$ & $\begin{array}{l}\text { Three hour session. } \\
\text { Initial whole group } \\
\text { introduction. } \\
\text { Two case studies ( } 50 \text { minutes } \\
\text { each) discussed in small } \\
\text { groups of 10-12, each with a } \\
\text { facilitator. Short break } \\
\text { between sessions. } \\
\text { Fictitious scenario used based } \\
\text { on real experiences of one of } \\
\text { the organisers. Characters in } \\
\text { the scenario drawn from each }\end{array}$ & $\begin{array}{l}\text { Three hour session. } \\
\text { Initial whole group introduction. } \\
\text { Two case studies ( } 50 \text { minutes } \\
\text { each) discussed in small groups } \\
\text { of } 10-12 \text {, each with a facilitator. } \\
\text { Short break between sessions. } \\
\text { Fictitious scenario used based } \\
\text { on real events of one of the } \\
\text { organisers. The scenario } \\
\text { provides the context for } \\
\text { students to discuss the legal, } \\
\text { ethical and moral codes }\end{array}$ & $\begin{array}{l}\text { Three hour session for debate } \\
\text { preparation, and two hour session for } \\
\text { the debate competition. } \\
\text { All students attend introduction to the } \\
\text { debates. } \\
\text { Students are divided into debate } \\
\text { teams according to debate motions } \\
\text { and each side of the debate motion. } \\
\text { Approx } 3 \text { Medicine and } 2 \text { Social Work } \\
\text { students make up each debate team. } \\
\text { Approx } 4 \text { debate motions on end of life } \\
\text { care are provided. }\end{array}$ \\
\hline
\end{tabular}




\section{of the professional groups} represented among the students. Events in the scenario depict situations intended to prompt

Approximately 20 small groups of 7-8 students, each facilitated by a tutor from Clinical Psychology, Medicine or Social Work.

Students each bring a case from their training where ethical issues have been important. Students present their case briefly to the group and the group decides on a case to analyse during the session.

The students choose a member of their group to chair the session. The student describes the details of the case to the group. The group decide which of 4 possible ethical frameworks to apply to the case.

All students are involved in the process and discussions. The group can ask further questions about the case along the way. end. ( professi ethical reasoning and lega obligations. surround a patient's capacity assessment. This session builds upon theoretical knowledge, reasoning and understanding of moral, ethical and professional codes through effective communication and team working. Students also have the opportunity to ask questions of each other's responses to the scenario.

Whole group debrief at the end. ebrief at the

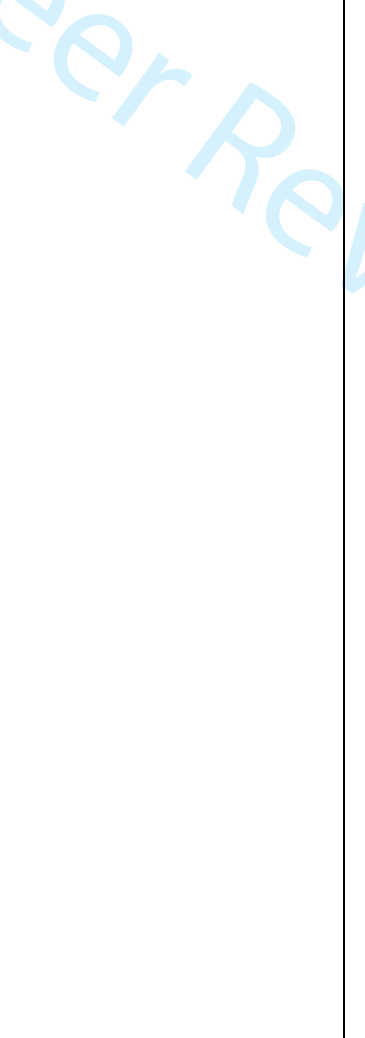

Students work in debate teams arguing for or against a specific debate motion using resource packs to prepare debate presentations. Facilitators from Social Work and Medicine are on hand for student support.

During the debate preparation sessions, students need to decide which members of their team will present their arguments $\left(3\right.$ mins $1^{\text {st }}$ speaker, and 2 mins $2^{\text {nd }}$ speaker) and which 2-3 members will answer questions from the audience and judges. Teams also need to decide on a team name.

The debate competition involves a tutor from each department acting as Chair of the debates. An overview of the debate competition format, rules, motions is provided at the start by the Chair for the judges. The Chair will also act as timekeeper.

Each debate lasts 20 minutes. The first speaker arguing for the motion is asked to start ( 3 mins), followed by the first speaker from the opposing team ( 3 mins). The rebuttal from each team then takes place ( 2 mins each side).

The audience made up of students and the judges are invited by the Chair to ask questions to each team. The 


\begin{tabular}{|c|c|c|c|}
\hline & $\begin{array}{l}\text { The session is roughly divided } \\
\text { into three: the first part is } \\
\text { working through the case, } \\
\text { referring to the ethical } \\
\text { framework in order to gather } \\
\text { the 'facts' of the case; the } \\
\text { second part, the group decide } \\
\text { upon 'guidance/advice' for the } \\
\text { student delivering the case; } \\
\text { and the third part of the } \\
\text { session is for reflection on } \\
\text { using the ethical frameworks, } \\
\text { on providing advice and } \\
\text { guidance to a colleague on an } \\
\text { ethical dilemma and working } \\
\text { in an interprofessional team. }\end{array}$ & & $\begin{array}{l}\text { students are allowed to confer for up } \\
\text { to } 30 \text { seconds before responding to } \\
\text { the question. } \\
\text { The Judges decide which team wins } \\
\text { each debate and uses a mark sheet to } \\
\text { arrive at their decision. The judges give } \\
\text { feedback to both teams before } \\
\text { announcing the winning team. A small } \\
\text { prize is given to each member of the } \\
\text { winning team. } \\
\text { The judging panel are those with a } \\
\text { professional or personal experience } \\
\text { relating to the debate topics. The } \\
\text { judges form a panel discussion at the } \\
\text { end of the debate based on the debate } \\
\text { motions, which provides students with } \\
\text { the opportunity to ask questions. }\end{array}$ \\
\hline $\begin{array}{l}\text { To whom the } \\
\text { activity is } \\
\text { delivered }\end{array}$ & $\begin{array}{l}\text { Approximately } 150 \text { students in } \\
\text { total, with roughly equal } \\
\text { numbers from each } \\
\text { professional group, i.e. Clinical } \\
\text { Psychology, Social Work, and } \\
\text { Medicine. }\end{array}$ & $\begin{array}{l}\text { Approximately } 100 \text { students in total, with roughly equal } \\
\text { numbers from each profession group i.e. Medicine and } \\
\text { Paramedicine. }\end{array}$ & $\begin{array}{l}\text { Approximately } 90 \text { students in total, } \\
\text { with approx. } 504^{\text {th }} \text { year } \\
\text { Undergraduate Medical students and } \\
\text { approx. } 40 \text { Masters Social Work } \\
\text { students. }\end{array}$ \\
\hline $\begin{array}{l}\text { By whom the } \\
\text { activity is } \\
\text { delivered }\end{array}$ & $\begin{array}{l}\text { Facilitated by tutors from } \\
\text { Clinical Psychology, Medicine } \\
\text { and Social Work departments. } \\
\text { The student briefing is } \\
\text { delivered in person or }\end{array}$ & $\begin{array}{l}\text { Facilitated by tutors from Paramedicine and Medicine } \\
\text { departments. } \\
\text { The introduction and debrief to the entire student group is co- } \\
\text { delivered by a tutor from each department. }\end{array}$ & $\begin{array}{l}\text { Facilitated by tutors from Medicine } \\
\text { and Social Work departments. } \\
\text { The introduction to the debates is co- } \\
\text { delivered by tutors from each }\end{array}$ \\
\hline
\end{tabular}




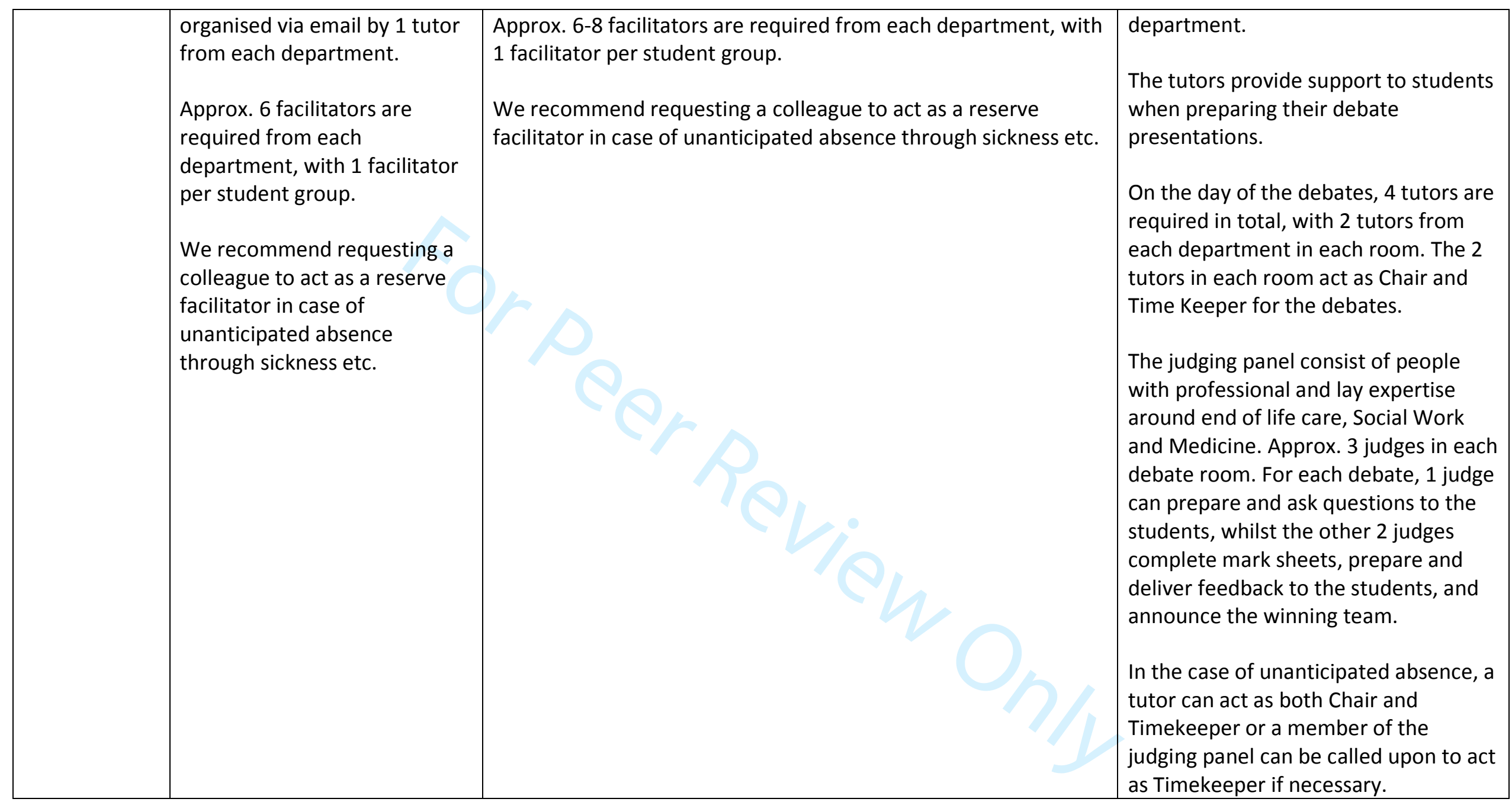

Structure adapted from Thistlethwaite, 2012 
Table 2: Example feedback sheet for ethics-orientated IPE

\begin{abstract}
Seeking feedback is important for two reasons. It helps the organisers to improve and develop the format and material for future sessions. It also challenges participants to reflect on what they have covered, which reinforces important learning points.
\end{abstract}

Please spend a few minutes thinking about your answers to the following questions, and write down your impressions. This is an important part of your learning, and we do value your comments and suggestions

1. In what way has the session challenged or changed your attitude to professionalism and working in interdisciplinary teams?

2. What have you learned about dealing with patients whose behaviour or thoughts pose significant challenges?

3. What have you learned about challenging the behaviour of professional colleagues?

4. What skills have you learned about working through legal or ethical problems? 